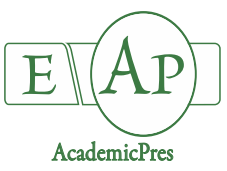

Hajnaczki S et al. (2021)

Notulae Botanicae Horti Agrobotanici Cluj-Napoca

Volume 49, Issue 1, Article number 12197

DOI: $10.15835 /$ nbha49112197

Note

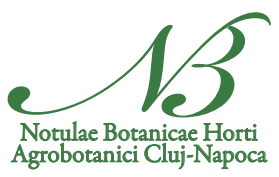

\title{
Solidago gigantea Ait. and Calamagrostis epigejos (L) Roth invasive plants as potential forage for goats
}

\author{
Sándor HAJNÁCZKI ${ }^{1}$, Ferenc PAJOR ${ }^{2 *}$, Norbert PÉTER ${ }^{1}$, \\ Ákos BODNÁR², Károly PENKSZA ${ }^{1}$, Péter PÓTI ${ }^{2}$ \\ ${ }^{1}$ Hungarian University of Agriculture and Life Sciences, Institute of Crop Production, H-2100, Páter Károly street 1, Gödölló \\ Hungary;sandor.hajnaczki@gmail.com,peter.norbert87@gmail.com,penksza.karoly@uni-mate.hu \\ ${ }^{2}$ Hungarian University of Agriculture and Life Sciences, Institute of Animal Husbandry, H-2100, Páter Károly street 1, Gödöllö \\ Hungary; pajor.ferenc@uni-mate.hu ("correspondingauthor);bodnar.akos@uni-mate.hu,poti.peter@uni-mate.hu
}

\begin{abstract}
The experiment focused on feed evaluation was conducted with goats to determine the feeding value of two aggressive weeds, the giant goldenrod (Solidago gigantea) and the bushgrass (Calamagrostis epigejos). Studied plants at the pre bloom stage were evaluated for feeding value by 7 -month-old castrated goats $(\mathrm{n}=5$ per group, BW=25.0 kg). All animals received no supplemental feed. The two plants differed in content of dry matter (DM) (266 vs. $394 \mathrm{~g} / \mathrm{kg}$ ) as well as in crude protein (119 vs. $86 \mathrm{~g})$, crude fibre (222 vs. $317 \mathrm{~g})$ and $\mathrm{N}$-free extract ( 523 vs. $447 \mathrm{~g}$ ) per kg DM. In this study, total daily DM intake from giant goldenrod and bushgrass was similar ( 666 vs. $689 \mathrm{~g} /$ goat). Apparent digestibility of these plants was similar for organic matter (58-59\%), but differed for crude protein (71 vs 53\%) and $\mathrm{N}$-free extract (72-62\%). The values of total digestible nutrients (55.9-53.4\%), net energy for maintenance (NEm: 4.90-4.54 MJ) and net energy for lactation (NEl: 5.16-4.91 MJ) per kg DM were similar. The study concluded that Solidago gigantea and Calamagrostis epigejos aggressive plants could be interesting feed for goats due to their feeding values. In addition, both of these aggressive weeds are relatively easily available.
\end{abstract}

Keywords: Calamagrostis epigejos; digestibility; feeding value; goat; Solidago gigantea

\section{Introduction}

Invasive alien species (IAS) have a great negative effect not only on the natural ecosystems but also for economics or human health (EEA, 2013; Schindler et al., 2015). European Union (EU) is recognised the IAS importance, and it reflected in EU regulation 1143/2014 on IAS (EU, 2014). It is estimated that 300-350 thousand hectares of fallow lands have been created over the past 50 years in Hungary. There are many undesirable, invasive, expansive weeds that can spread on the abandoned spaces or fallow lands (e.g. Somodi $e t$ al., 2008). These aggressive plants often growth monodominantly and quickly, thus reducing the species richness of the fields (Fiala et al., 2003; Holub et al., 2012). In dry grasslands Festuca species predominated, creating species-rich vegetation that could be greatly degraded by invasive species degradation (Török et al., 2018). One of the most interesting invasive plant is the giant goldenrod (Solidago gigantea), whilst relative

Received: 21 Dec 2020. Received in revised form: 27 Jan 2021. Accepted: 29 Jan 2021. Published online: 09 Feb 2021.

From Volume 49, Issue 1, 2021, Notulae Botanicae Horti Agrobotanici Cluj-Napoca journal will use article numbers in place of the traditional method of continuous pagination through the volume. The journal will continue to appear quarterly, as before, with four annual numbers. 
expansive plant is also the bushgrass (Calamagrostis epigejos). In agriculture, giant goldenrod and bushgrass are mainly grow on abandoned arable fields and pastures and they easily become dominant, suppressed other valuable plant species and spread aggressively. Both these problematic species are mainly found in central Europe (Rebele and Lehmann 2001; Fiala et al., 2003). The agrotechnical methods for suppressing both plants are available when the main methods are the mowing and grazing, but these plants need long-term period to disappear (Házi et al., 2011; Henning et al., 2017). Unfortunately, still little is known whether invasive or expansive plants are suitable for ruminants' feeding (Hang et al., 2011). Despite the few reports studying the reducing invasive plants occurrence, to the best of our knowledge this is the first study to evaluate the giant goldenrod and bushgrass plants as feed. Recently, there were many publications about the ecology of Solidago gigantea and Calamagrostis epigejos (Rebele and Lehman, 2001; Botta-Dukát and Dancza, 2008). However, feeding value and digestibility of these plants have not yet been determined.

Therefore, the main aim of the present study was to evaluate the feeding value (nutritional composition, daily intake and digestibility) of giant goldenrod (Solidago gigantea) and bushgrass (Calamagrostis epigejos) and our hypothesis was that both these aggressive plants can become interesting feeds for goats in terms of their nutritional value and availability.

\section{Materials and Methods}

\section{Study site}

A feeding trial was conducted with Hungarian Native goats at a goat farm in Kaposdada (Hungary) in fall of 2019. The giant goldenrod (Solidago gigantea) and the bushgrass (Calamagrostis epigejos) were original and were used in this trial being in the pre bloom stage and grown at the same site. Originally in this site the dominant vegetation types were Salvinio nomorosae and Festucetum rupicolae, but in some places invasive species became dominant.

\section{Experimental design}

Ten 7-months-old Hungarian native castrated male goats (body weight: $25 \mathrm{~kg}$ ) were randomly allocated to two treatment groups according to two plants. The feeding period included 7 days for adaptation to forages, followed by 7 days of digestibility trial while the giant goldenrod and the bushgrass cut plants were fed. Goats were then kept in individual metabolism boxes, which were $1 \mathrm{~m}^{2}$ per animal. The whole plants were mown by hand ca. $5 \mathrm{~cm}$ above ground level each day at $5 \mathrm{pm}$. The daily feed allotment in both periods was given in two identical feeds at $6 \mathrm{pm}$. and next day at $8 \mathrm{am}$. Drinking water and salt blocks were available ad libitum. Feeding residues were collected; weighted and daily intakes were recorded per animal. Faeces were individual collected by goats at 24-hr intervals over the last 5 days, each day at $6 \mathrm{pm}$., from 5 -days amount composite samples ( 50 g) were prepared and stored frozen $\left(-20^{\circ} \mathrm{C}\right)$ until analysed. Fresh forage and faecal samples were analysed for dry matter, crude protein ( $\mathrm{N} \times 6.25)$, crude fibre, ether extracts and ash according to Weende analysis (Hungarian Feed Codex, 2004). Total digestible nutrients (TDN), digestible energy (DE), metabolizable energy $(\mathrm{ME})$ and net energy for maintenance (NEm) were calculated by regression formulas descripted by Schmidt et al. (2000).

\section{Statistical analysis}

Statistical analysis was processed by the SPSS 25.0 software package (IBM Corporation, Armonk, NY, USA). Statistical analysis was carried out in order to determine the effect of plants (fixed effect) on daily intake, digestibility and energy content as dependent variables. Means were compared by F-test (equality of variances) and Student's t-test (significance of difference) in case of normal distribution (Shapiro-Wilk's test). Since data were not normally distributed, variables were subjected to Mann-Whitney U test. Data were expressed as mean \pm SD. Significance was taken at an alpha level of 0.05 . 


\section{Results}

The nutritional composition of both investigated invasive plants was quite different (Table 1).

Table 1. Nutrient composition of the two plants fed to goats

\begin{tabular}{|c|c|c|}
\hline Item & Solidago gigantea & Calamagrostis epigejos \\
\hline Dry matter $(\mathrm{DM})(\mathrm{g} / \mathrm{kg}$ fresh forage) & 266.5 & 393.8 \\
\hline Crude protein $(\mathrm{g} / \mathrm{kg} \mathrm{DM})$ & 119.3 & 85.8 \\
\hline Ether extract $(\mathrm{g} / \mathrm{kg} \mathrm{DM})$ & 46.8 & 31.8 \\
\hline Crude fibre $(\mathrm{g} / \mathrm{kg} \mathrm{DM})$ & 222.4 & 317.2 \\
\hline Ash $(\mathrm{g} / \mathrm{kg} \mathrm{DM})$ & 88.7 & 118.1 \\
\hline Nitrogen-free extracts $(\mathrm{g} / \mathrm{kg} \mathrm{DM})$ & 522.8 & 447.1 \\
\hline
\end{tabular}

Dry matter, crude protein and crude fibre contents of giant goldenrod were $266.5 \mathrm{~g} / \mathrm{kg}$ plant, $119.3 \mathrm{~g} / \mathrm{kg}$ dry matter (DM) and $222.4 \mathrm{~g} / \mathrm{kg}$ DM. In contrast, in bushgrass the contents of dry matter and crude fibre were higher $(393.8 \mathrm{~g} / \mathrm{kg}$ plant and $317.2 \mathrm{~g} / \mathrm{kg} \mathrm{DM})$ and the content of crude protein was lower $(85.8 \mathrm{~g} / \mathrm{kg} \mathrm{DM})$ compared to giant goldenrod.

In the feeding trial, the offered amount per day of bushgrass and giant goldenrod whole plants per one goat were the same ( 3 - $3 \mathrm{~kg}$ ); but their total consumptions were different, $2.75 \mathrm{~kg}$ for giant goldenrod, versus $1.75 \mathrm{~kg}$ for bushgrass (Table 2 ).

Table 2. Daily intake of the two plants fed to goats

\begin{tabular}{|c|c|c|}
\hline Item & Solidago gigantea & Calamagrostis epigejos \\
\hline Offered amount (kg) & 3.0 & 3.0 \\
\hline Daily intake $(\mathrm{kg})$ & $2.5 \pm 0.13$ & $1.75 \pm 0.10$ \\
\hline Daily DM intake $(\mathrm{kg})$ & $0.666 \pm 0.03$ & $0.689 \pm 0.04$ \\
\hline DM intake / BW (\%) & $2.66 \pm 0.14$ & $2.76 \pm 0.16$ \\
\hline
\end{tabular}

In contrast, DM intakes only slightly differed (by $23 \mathrm{~g}$ ) per day, as well as in percent bodyweight (by 0.10 $\%)$, respectively. In this study, goats utilised of these plants' biomass without preference for leaves over stems. The rationale lies in the fact that these invasive weeds were pre bloom stage; in this stage, whilst the leaves and stems were even fairly digestible.

The apparent digestibility of the giant goldenrod's crude protein content was more favourable $(71 \%)$ compared to bushgrass (Table 3 ).

Table 3. Apparent digestibility values of the two plants fed to goats

\begin{tabular}{|c|c|c|}
\hline Item & Solidago gigantea & Calamagrostis epigejos \\
\hline Crude protein (\%) & $71 \pm 4.50^{\mathrm{b}}$ & $53 \pm 4.24^{\mathrm{a}}$ \\
\hline Crude fat (\%) & $44 \pm 3.00^{\mathrm{b}}$ & $24 \pm 5.94^{\mathrm{a}}$ \\
\hline Crude fibre (\%) & $23 \pm 3.95^{\mathrm{a}}$ & $61 \pm 3.31^{\mathrm{b}}$ \\
\hline Nitrogen-free extracts (\%) & $72 \pm 3.52^{\mathrm{b}}$ & $62 \pm 3.18^{\mathrm{a}}$ \\
\hline Organic materials (\%) & $58 \pm 3.69$ & $59 \pm 2.95$ \\
\hline
\end{tabular}

The apparent digestibility values of bushgrass crude protein was average (53\%). In contrast, crude fibre digestibility was found good (61\%) in bushgrass, while giant goldenrod's crude fibre digestibility value was significantly lower $23 \%$.

The Total digestible nutrients (TDN) and nett energy (NEm and NEl) contents of the bushgrass and the giant goldenrod plants were slightly different (Table 4). 
Table 4. Energy content of the two plants fed to goats

\begin{tabular}{|c|c|c|}
\hline Item & Solidago gigantea & Calamagrostis epigejos \\
\hline $\mathrm{TDN}(\% \mathrm{DM})$ & $55.9 \pm 3.89$ & $53.4 \pm 2.53$ \\
\hline $\mathrm{DE}(\mathrm{MJ} / \mathrm{kg} \mathrm{DM})$ & $10.31 \pm 0.72$ & $9.85 \pm 0.47$ \\
\hline $\mathrm{ME}(\mathrm{MJ} / \mathrm{kg} \mathrm{DM})$ & $8.45 \pm 0.59$ & $8.08 \pm 0.38$ \\
\hline $\mathrm{NE}_{\mathrm{m}}(\mathrm{MJ} / \mathrm{kg} \mathrm{DM})$ & $4.90 \pm 0.56$ & $4.54 \pm 0.37$ \\
\hline $\mathrm{NE}_{\mathrm{l}}(\mathrm{MJ} / \mathrm{kg} \mathrm{DM})$ & $5.16 \pm 0.39$ & $4.91 \pm 0.26$ \\
\hline
\end{tabular}

Giant goldenrod's TDN value was 55.9\% in DM kg, NEm and NEl values were 4.90 and 5.16 MJ / DM kg. Bushgrass's TDN value was $53.4 \%$ in DM kg, NEm and NEl values were 4.54 and 4.91 MJ / DM.

\section{Discussion}

The giant goldenrod plant had relatively low dry matter (DM) content. However, this fact is consistent with most green roughage. Moreover, the dry matter and crude fibre content of the giant goldenrod is similar, but crude protein was greatly lower than values reported for foliage of most forage from pasture. There are basics in diets of ruminant species, which supports our thesis that the goats that utilizes high dry matter content is the most suitable for grazing the Calamagrostis epigejos. Other dicotyledonous species, and the group of grasses and legumes, not reached the values of Solidago gigantea or Calamagrostis epigejos in terms of nitrogenfree extracts and ether extract. The high ether extract content provides a good basis for supplementary feeding with high protein feeds to the test species and can facilitate good utilization of this protein content.

The need for supplementary feeding is also supported by the fact that the crude protein content of both investigated plant species is only about two thirds of the total crude protein content of grasses and legumes in grasslands. The crude fibre content of the Solidago gigantea is close to that of the grass, since in the phenophase examined the giant goldenrod's stem is still soft, not woody and its leaf mass is also large and easy to consume.

Both plant species proved fairly digestible in goats. Values of investigated parameters are within the ranges for ruminants reported by Schmidt et al. (2000). The apparent digestibility coefficients for crude protein, crude fibre, crude fat and $\mathrm{N}$-free extracts were in bushgrass significantly $(\mathrm{P}<0.05)$ lower compared with giant goldenrod, while organic material values were similar, respectively.

The apparent digestibility of the giant goldenrod's crude protein content was more favourable (71\%), but crude fibre digestibility was lower (23\%) compared to bushgrass ( $53 \%$ and $61 \%$ ).

Low digestibility value of crude fibre in giant goldenrod may be due to the high content of saponin. Earlier reported that the triterpenoid saponins content and of giant goldenrod are significant, approximately is 8-9 \% (Botta-Dukát and Dancza, 2008; Mietlinska et al., 2019). The triterpenoid saponins are selectively influenced the rumen bacteria and fermentation (Patra and Saxena, 2009), which might decrease the bacterial crude fibre digestion in rumen. Moreover, saponins have inhibit effect on rumen protozoa, which alter rumen protein metabolism, increase the efficiency of microbial protein synthesis and protein flow to duodenum (Patra and Saxena, 2009; Wang et al., 2012). In this way, saponins may have favourable effect on crude protein digestion.

The apparent digestibility of the giant goldenrod's crude protein is only slightly lower than that of the grass, alfalfa or other legumes (at flowering about 60\%), and is similarly favourable for the apparent digestibility of $\mathrm{N}$-free extracts, digestibility value also for alfalfa before budding (76\%)( Schmidt et al., 2000). The apparent digestibility of bushgrass crude fibre is moderate, similar with grasses and legumes species values (Schmidt et al., 2000).

The TDN and nett energy contents of the Solidago gigantea and the Calamagrostis epigejos plants were relatively similar, however NEm and NEl values slightly differed between both plants by $8 \%$ and $5 \%$. The energy values (NEm and NEl) are comparable to other forage plants. The data clearly show that the giant goldenrod and bushgrass have significantly better energy content (NEm) than any group of pasture plants, and 
the values of beginning of flowering alfalfa (4.71MJ / kg DM) (Schmidt et al., 2000). In calculating the net energy for lactation, the giant goldenrod value was comparatively similar to grassland values $(5.28 \mathrm{MJ} / \mathrm{kg}$ of feed) and exceeds the value of alfalfa before flowering (5.02MJ / kg DM) (Schmidt et al., 2000), while the bushgrass was almost $10 \%$ below.

The Solidago gigantea and the Calamagrostis epigejos, can be used primarily to satisfy the net energy for maintenance and lactation based on the nutritional studies. In addition, any of the investigated species may be recommended for goat herds.

\section{Conclusions}

The results of our study show that goats consume Solidago gigantea and Calamagrostis epigejos at pre blooming stage without any problems. Our study also suggest that both these species can play a significant role in feeding goats due to their feeding value. Another advantage of both of these aggressive weeds is their relatively easy availability. In addition, feeding of both plants by goats can help to reduce invasive plants occurrence.

\section{Authors' Contributions}

Conceptualization: SH and PP; Data curation: FP; Formal analysis: PF; Funding acquisition: KP; Investigation: $\mathrm{SH}$; Methodology: NP and ÁB; Project administration: $\mathrm{SH}$; Supervision: $\mathrm{KP}$ and PP; Validation: NP and PP; Writing - original draft: SH, FP and KP; Writing - review \& editing: FP, NP, ÁB and KP. All authors read and approved the final manuscript.

\section{Acknowledgements}

This work is supported by the EFOP-3.6.3-VEKOP-16-2017-00008 project. The project is co-financed by the European Union and the European Social Fund. This work was supported by Higher Education Institutional Excellence Program awarded by the Ministry for Innovation and Technology (grant number NKFIH-1159-6/2019) and OTKA Program (grant number K-125423).

\section{Conflict of Interests}

The authors declare that there are no conflicts of interest related to this article.

\section{References}

Botta-Dukát Z, Dancza I (2008). Giant and Canadian goldenrod (Solidago gigantea Ait., S. canadensis L.). In: BottaDukát Z, Balogh L (Eds). The most important invasive plants in Hungary. Institute of Ecology and Botany of the Hungarian Academy of Sciences, Vácrátót, pp 167-177.

European Environment Agency (2013). Invasive alien species: a growing problem for environment and health. Retrieved 2020 November 27 from https://www.eea.europa.eu/highlights/invasive-alien-species-a-growing

European Union (EU) (2014). Commission regulation (EU) No 1143/2014 of the 22 October 2014 on the prevention and management of the introduction and spread of invasive alien species. Retrieved 2020 November 2 from http://data.europa.eu/eli/reg/2014/1143/oj 
Fiala K, Holub P, Sedláková I, Tůma I, Záhora J, Tesařová M (2003). Reasons and consequences of expansion of Calamagrostis epigejos in alluvial meadows of landscape affected by water control measures. Ekológia (Bratislava) 22:242-252.

Hang BPT, Lam V, Phuong TTB, Preston TR (2011). Water hyacinth (Eichhornia crassipes): an invasive weed or a potential feed for goats? Livestock Research for Rural Development 23(7):152.

Házi J, Bartha S, Szentes S, Wichmann B, Penksza K (2011). Seminatural grassland management by mowing of Calamagrostis epigejos in Hungary. Plant Biosystems 145(3):699-707. https://doi.org/10.1080/11263504.2011.601339

Henning K, Tischewa S (2017). Year-round cattle and horse grazing support the restoration of abandoned, dry sandy grassland and heathland communities by supressing Calamagrostis epigejos and enhancing species richness. Journal of Nature Conservation 40:120-130. https://doi.org/10.1016/j.jnc.2017.10.009

Holub P, Tůma I, Záhor J, Fiala K (2012). Different nutrient use strategies of expansive grasses Calamagrostis epigejos and Arrhenatherum elatius. Biologia 67:673-680. https://doi.org/10.2478/s11756-012-0050-9

Hungarian Feed Codex (2004). II/2 OMMI, Budapest.

Mietlińska K, Przybyt M, Kalemba D (2019). Polish plants as raw materials for cosmetic purposes. Biotechnology and Food Science 83(2):95-106. https://doi.org/10.34658/bfs.2019.83.2.95-107

Patra AK, Saxena J (2009). The effect and mode of action of saponins on the microbial populations and fermentation in the rumen and ruminant production. Nutrition Research Reviews 22(2):204-219. https://doi.org/10.1017/S0954422409990163

Rebele F, Lehmann C (2001). Biological flora of Central Europe: Calamagrostis epigejos (L.) Roth. Flora 196(5): $325-$ 344. https://doi.org/10.1016/S0367-2530(17)30069-5

Schindler S, Staska B, Adam M, Rabitsch W, Essl F (2015). Alien species and public health impacts in Europe: a literature review. NeoBiota 27:1-23. https://doi.org/10.3897/neobiota.27.5007

Schmidt J, Várhegyi Jné, Várhegyi J, Túriné CÉ (2000). Kérődzők fehérjeértékelési rendszere [The evaluation of ruminant feedstuffs for energy and protein content]. Mezőgazda Kiadó. Budapest pp 144-163.

Somodi I, Virágh K, Podani J (2008). The effect of the expansion of the clonal grass Calamagrostis epigejos on the species turnover of a semi-arid grassland. Applied Vegetation Science 11:187-192. https://doi.org/10.3170/2008-7-18354

Török P, Penksza K, Tóth E, Kelemen A, Sonkoly J, Tóthmérész B (2018). Vegetation type and grazing intensity jointly shape grazing on grassland biodiversity. Ecology and Evolution 8:10326-10335. https://doi.org/10.1002/ece3.4508

Wang JK, Ye JA, Liu JX (2012). Effects of tea saponins on rumen microbiota, rumen fermentation, methane production and growth performance-a review. Tropical Animal Health Production 44:697-706.

https://doi.org/10.1007/s11250-011-9960-8
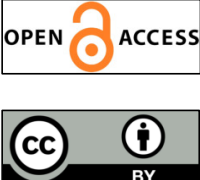

The journal offers free, immediate, and unrestricted access to peer-reviewed research and scholarly work. Users are allowed to read, download, copy, distribute, print, search, or link to the full texts of the articles, or use them for any other lawful purpose, without asking prior permission from the publisher or the author.

License - Articles published in Notulae Botanicae Horti Agrobotanici Cluj-Napoca are Open-Access, distributed under the terms and conditions of the Creative Commons Attribution (CC BY 4.0) License. (c) Articles by the authors; UASVM, Cluj-Napoca, Romania. The journal allows the author(s) to hold the copyright/to retain publishing rights without restriction. 